\title{
PACIENTŲ, PATENKANČIŲ İ RIZIKOS VEIKSNIŲ GRUPE, POŽIŪRIS İ ŠIIRDIES IR KRAUJAGYSLIŲ LIGAS BEI ŠIRDIES IR KRAUJAGYSLIŲ LIGŲ PREVENCINES PROGRAMAS
}

\author{
Vilma Rastenienè, Loreta Lastauskienè \\ Kauno kolegijos Medicinos fakultetas
}

Raktažodžiai: širdies ir kraujagyslių ligos, širdies ir kraujagyslių ligų prevencinès programos

\begin{abstract}
Santrauka
Politiniai, ekonominiai, socialiniai pastarujų metu pokyčiai turejo įtakos Lietuvos gyventojų sveikatai. Lietuvos gyventojų mirties priežasčių struktūra jau daugelị metų išlieka nepakitusi. 2013 m. nuo kraujotakos sistemos ligų miré daugiau nei pusè, t.y. 56,3 proc. gyventojų. Pasiekti geresnių sveikatos rodiklių galima įtraukiant kuo daugiau gyventojų i sveiką gyvenseną skatinančias programas. Tačiau programas reikia tinkamai valdyti, todèl programos efektyvumo vertinimas yra labai svarbus elementas. Širdies ir kraujagyslių ligos visame pasaulyje siejamos su netinkama žmonių gyvensena: nesveika mityba (maiste per daug riebalų, cholesterolio, druskos), rūkymu, sumažèjusiu fiziniu aktyvumu, antsvoriu bei negydomu padidèjusiu arteriniu kraujospūdžiu ar cukriniu diabetu. Užsienio ir mūsų šalies patirtis rodo, kad galima išvengti daugelio širdies ir kraujagyslių ligų rizikos veiksnių bei pailginti žmonių gyvenimą. Programos tikslas yra suteikti pacientams galimybes prisiimti atsakingą vaidmenị sprendžiant savo ligos - simptomų monitoravimo, taisyklingo vaistų vartojimo, pagalbos poreikio situaciją. Šių intervencijų taikymas gali sumažinti išteklių naudojimą sveikatos priežiūros sistemoje.
\end{abstract}

\section{Ivadas}

2013 m. Lietuvoje hospitalinis sergamumas sergančių šrdies ir kraujotakos sistemos ligomis sudare 62,6 proc. 1000 gyventojų, vidutinè gulëjimo trukmè 14,1 dienos [3].

Nepaisant gydymo metodų pažangos pakartotinès hospitalizacijos skaičius išlieka didelis. Manoma, kad ši situacija nesikeis iki $2020 \mathrm{~m}$. Lietuvoje nuo širdies ir kraujagyslių ligu (ŠKLL) miršta daugiau kaip 54 proc. žmonių, o Europos šalyse mirštamumo nuo ŠKL vidurkis - 49 proc.
Todèl Lietuva išlieka pirmaujančia Europos šalimi pagal mirčių skaičių dẻl širdies ligų [9]. Širdies ir kraujagyslių ligos išlieka pagrindinè mirties priežastis Europoje, nors ir su dideliais mirtingumo skirtumais tarp šalių. Ligotumas ŠKL nuo 2001 iki 2012 ženkliai išaugo [7]. Palyginus 2004-2011 m. HFA duomenų bazèje valstybių pateiktus ligonių mirtingumo nuo kraujotakos sistemos ligų 100 000 gyventojų Lietuvoje, Latvijoje, Estijoje, Suomijoje, Vokietijoje, Norvegijoje, Švedijoje duomenis, matome, kad bendras mirtingumas nuo kraujotakos ligų Lietuvoje, Latvijoje ir Estijoje išlieka didžiausias lyginant su kitomis Europos Sajungos šalimis (Suomija, Vokietija, Norvegija, Švedija) [2].

Lietuvoje vykdoma „Asmenų, priskirtinų širdies ir kraujagyslių ligų didelės rizikos grupei, atrankos ir prevencijos priemonių finansavimo programa", patvirtinta Sveikatos apsaugos ministro $2005 \mathrm{~m}$. lapkričio $25 \mathrm{~d}$. ịsakymu Nr. V-913, skirta vyrų nuo 40 iki 55 metų ir moterų nuo 50 iki 65 metų širdies ir kraujagyslių ligų prevencijai. Programos priemonès taikomos vieną kartą per metus.

Metaboliniu sindromu sergantys pacientai ne rečiau kaip kas dvejus metus siunčiami pakartotinai išsitirti i širdies ir kraujagyslių ligų prevencinius padalinius.

Programa sukurta siekiant sumažinti sergamumą širdies ir kraujagyslių ligomis (krūtinès angina ar miokardo infarktu, smegenų išemija, insultu, periferinių arterijų tromboze), atrinkti sergančiuosius ateroskleroze ar cukriniu diabetu, kurie nejaučia sveikatos sutrikimų, užkirsti kelią šių ligų raidai. Programą igyvendina pirminès sveikatos priežiūros istaigos, sudariusios sutartis su teritorinemis ligonių kasomis, bei specializuoti širdies ir kraujagyslių ligų prevencijos padaliniai. Viena pagrindinių programos priemonių yra informavimo apie didelę širdies ir kraujagyslių ligų tikimybę, šios tikimybès ịvertinimo, pirminès prevencijos priemonių plano sudarymo ar siuntimo išsamiai įvertinti širdies ir kraujagyslių ligų tikimybę paslauga.

Koronarinès širdies ligos kilmè daugialypè. Todèl nepakanka nustatyti kurị nors vieną rizikos faktorių, būtina 
išaiškinti visus ir ịvertinti bendrają paciento riziką. Bendroji rizika vertinama Europos kardiologų draugijos rekomenduojamų lentelių pagalba. Pagal SCORE sistemą galima apskaičiuoti tikimybę mirti nuo koronarinès širdies ligos per artimiausius 10 metų.

SCORE“ (angl. Systemic Coronary Risk Evaluation) duomenų bazè sudaryta remiantis 12 Europos kohortinių tyrimų, panaudojus 250 tūkst. pacientų duomenis bei užregistravus 7 tūkst. mirčių nuo širdies ir kraujagyslių ligų. SCORE lentelèje pateikiami duomenys remiantis amžiaus, lyties, bendro cholesterolio, sistolinio kraujo spaudimo, rūkymo kriterijais.

Europos kardiologų draugijos pateikia šiuos SCORE sistemos privalumus: sistema paremta gausiais duomenimis, koronarinès širdies ligos ir insulto mirties rizika gali būti nustatyta atskirai, įmanoma sukurti elektroninę lentelès versiją, SCORE sistemos rizikos funkcija gali būti patikrinta pagal kiekvienos šalies mirtingumo rodiklius.

Pagal ministro ịsakymą, jeigu širdies ir kraujagyslių ligų tikimybe pagal SCORE - 5-10 proc., rekomenduojama keisti gyvenseną ir pritaikyti pirminès profilaktikos priemones. Jei nustatoma 11 ir daugiau procentų, rekomenduojama nuodugniai ištirti ir ịvertinti širdies ir kraujagyslių ligų tikimybę [6].

Pagrindinis prevencijos tikslas - sumažinti pirmojo ar pasikartojančio koronarinès širdies ligos (KŠL) pasireiškimo, išeminio insulto ar periferinių arterijų ligos (PAL) dažni, aktyviai veikiant rizikos veiksnius. Svarbiausia - invalidumo ir ankstyvų mirčių prevencija. Priemonių visuma, skirta apsaugoti pacientus nuo koronarinès širdies ligos pasireiškimų išaiškinant ir koreguojant provokuojančius rizikos veiksnius - tai pirminè koronarinès širdies ligos prevencija. Siekiant išvengti širdies ligų, reikia dirbti tarpdisciplininèje komandoje: sveikatos priežiūros paslaugų teikejjai, mokslininkai, akademinis personalas [1].

Tyrimo tikslas - nustatyti pacientų, patenkančių ị rizikos veiksnių grupę, požiūrį apie širdies ir kraujagyslių ligas bei širdies ir kraujagyslių ligų prevencines programas.

\section{Tyrimo objektas ir metodai}

Tirtas pacientų, patenkančių ị rizikos veiksnių grupę, požiūris ị širdies ir kraujagyslių ligas bei širdies ir kraujagyslių ligų prevencines programas.

Taikytas struktūrizuotos apklausos klausimynas raštu.

Tyrime dalyvavo 50 respondentų. Tiriamieji buvo pasirinkti patogiosios imties būdu. Tyrime dalyvavo 32 moterys (64\%) ir 18 vyru (36\%). Respondentai buvo pasirinkti pagal amžių, priklausantys didelei rizikos grupei. Tyrimas atliktas vienoje Lietuvos miesto X klinikoje.

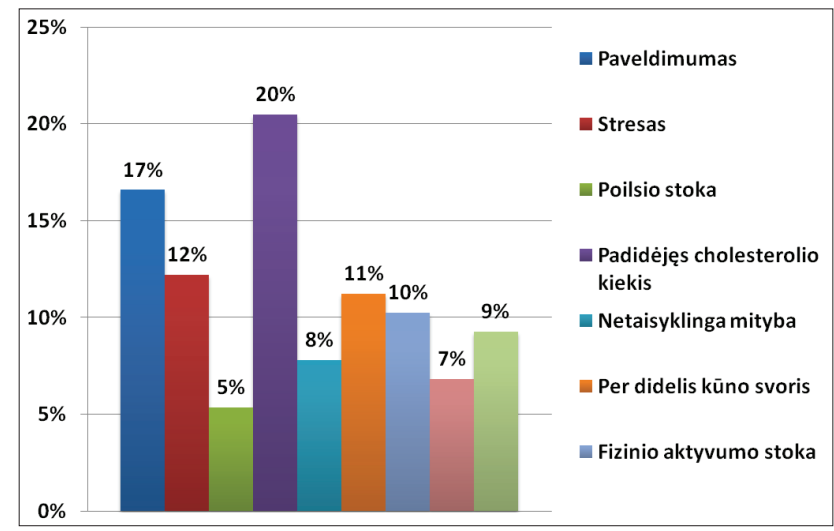

1 pav. Pagrindiniai širdies ir kraujagyslių ligų išsivystymo veiksniai $(n=75)$

1 lentelè. Sritys, kuriose pacientai pakeitė gyvenimo įpročius, dalyvaujant širdies ir kraujagyslių ligų programoje $(\mathrm{N}=27)$

\begin{tabular}{|c|c|c|}
\hline $\begin{array}{l}\text { Katego- } \\
\text { rija }\end{array}$ & $\begin{array}{l}\text { K a r - } \\
\text { totinių } \\
\text { s k a i - } \\
\text { čius }\end{array}$ & Autentiški pasisakymų fragmentai \\
\hline $\begin{array}{l}\text { Mitybos } \\
\text { ipročių } \\
\text { pokytis }\end{array}$ & 7 & 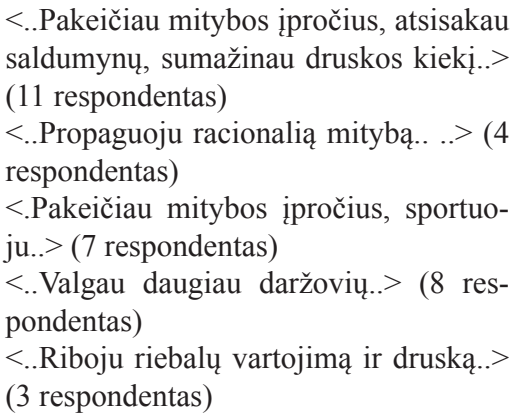 \\
\hline $\begin{array}{l}\text { Fizinio } \\
\text { akty- } \\
\text { vumo } \\
\text { pokytis }\end{array}$ & 11 & 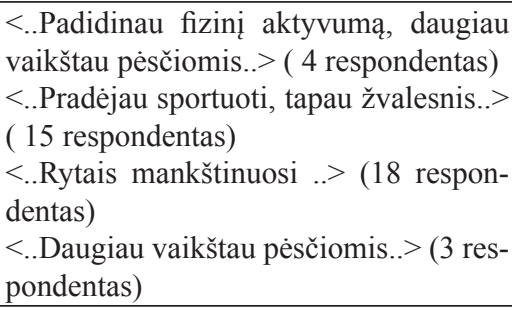 \\
\hline $\begin{array}{l}\text { Raci- } \\
\text { onalus } \\
\text { poilsis }\end{array}$ & 2 & $\begin{array}{l}<. . \text { Pakeičiau dienos réšimą, daugiau lai- } \\
\text { ko skiriu poilsiui..> (18 respondentas) } \\
<. . \text { Daugiau ilsiuosi..> ( } 14 \text { respondentas })\end{array}$ \\
\hline $\begin{array}{l}\text { Nèra po- } \\
\text { kyčių }\end{array}$ & 7 & $\begin{array}{l}<. . \text { Nieko nepakeičiau.. }>\text { (4 responden- } \\
\text { tas) } \\
<. . \text { Neturiu noro ir galimybių kažką keis- } \\
\text { ti.. }>\text { (2 respondentas) }\end{array}$ \\
\hline
\end{tabular}

\section{Tyrimo rezultatai}

Pagrindiniai rizikos veiksniai, respondentų nuomone, 
yra padidejęs cholesterolio kiekis kraujyje (20\%), kiek mažiau svarbus paveldimumas $(17 \%)$ bei stresas $(12 \%)$. Mažiausiai svarbus rizikos veiksnys, respondentų nuomone, poilsio stoka (5\%). Padidejusi cholesterolio koncentracija yra vienas svarbiausių veiksnių, nulemiančių širdies ir kraujagyslių ligų atsiradimą. Rizikos veiksnių mažinimas turi didelę reikšmę gyvenimo kokybei, todèl labai svarbu siekti veiksmingos širdies ir kraujagyslių ligų profilaktikos, kuri padètų sustabdyti didejjantį sergančių širdies ligomis pacientų skaičių.

Tyrimo duomenimis, nedidele dalis (4\% respondentų) turi padidejusị kraujospūdị apie 1 metus, $12 \%$ respondentu apie 1-5 metus, $18 \%$ turipadidintąkraujo spaudimą 5-10 metu

2 lentelė. Motyvai, dèl kurių keistų gyvenimo būdą $(\mathrm{N}=27)$

\begin{tabular}{|c|c|c|}
\hline $\begin{array}{l}\text { Kate- } \\
\text { gorija }\end{array}$ & $\begin{array}{l}\text { Kar- } \\
\text { totiniụ } \\
\text { skai- } \\
\text { čius }\end{array}$ & Autentiški pasisakymų fragmentai \\
\hline $\begin{array}{l}\text { Svei- } \\
\text { katos } \\
\text { pablo- } \\
\text { gèjimo } \\
\text { baimè }\end{array}$ & 14 & 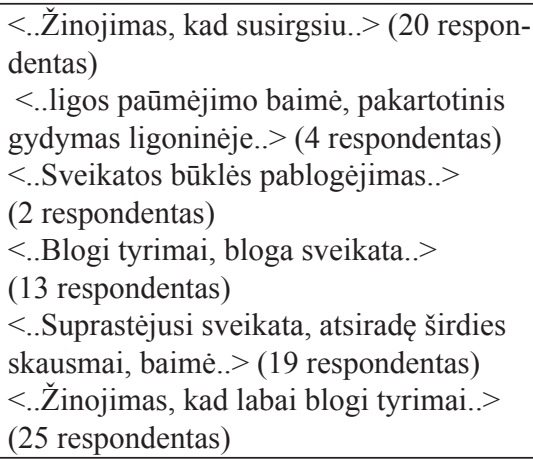 \\
\hline $\begin{array}{l}\text { Kom- } \\
\text { plika- } \\
\text { cijų } \\
\text { baimé }\end{array}$ & 6 & $\begin{array}{l}\text { Galvos svaigimas bei padidėjęs kraujo } \\
\text { spaudimas dėl netinkamo rėžimo gali } \\
\text { sukelti komplikacijas..> ( } 6 \text { respondentas) } \\
<\text {.Našta šeimos nariams, negalejjimas } \\
\text { dirbti..> ( } 21 \text { respondentas) }\end{array}$ \\
\hline $\begin{array}{l}\text { Papil- } \\
\text { domos } \\
\text { finan- } \\
\text { sinès } \\
\text { išlai- } \\
\text { dos }\end{array}$ & 5 & $\begin{array}{l}\text { <..Papildomos finansinès išlaidos..> } \\
(27 \text { respondentas) } \\
<. . \text { Nežinau kas paskatintų keisti gyve- } \\
\text { nimo būdą. Pasigendu šeimos narių, } \\
\text { gydytojų pagalbos. Pablogejjus sveikatai } \\
\text { reikės papildomai vaistų, kurie brangiai } \\
\text { kainuoja..> (20 respondentas) } \\
<. . \text { Nežinau, bijau papildomų išlaidų..> } \\
\text { (16 respondentas) }\end{array}$ \\
\hline $\begin{array}{l}\text { Teigia- } \\
\text { mos } \\
\text { emoci- } \\
\text { jos }\end{array}$ & 4 & $\begin{array}{l}<. . \text { Tapau žvalesnis, geresnès nuotai- } \\
\text { kos..> }(4 \text { respondentas }) \\
<. . \text { Bendravimas su kitais pacientais, spe- } \\
\text { cialistais, paskata keisti ịpročius. }>(15 \\
\text { respondentas }) \\
<. . \text { Supratimas.. }>\text { (8 respondentas })\end{array}$ \\
\hline
\end{tabular}

ir 12\% - 10 ir daugiau metų. Apie pusė respondentų (54\%) nurode, kad kraujo spaudimas yra normos ribose. Kraujo spaudimo padidejjimas - pavojingas širdies ir kraujagysliu ligų rizikos veiksnys. Todèl labai svarbu, kad kraujo spaudimas būtų laiku koreguojamas, kadangi tik tuomet galima būtų išvengti širdies ir kraujagyslių ligų ar jų komplikacijų.

Cukrinis diabetas bei sutrikusi glikemija kraujyje taip pat turi įtakos širdies ir kraujagysliu ligoms. Todèl labai svarbu, kad pacientai žinotų ir sektų gliukozès kiekį kraujyje, laiku pastebètų jo pokyčius. Atlikus tyrimą paaiškèjo, $\operatorname{kad} 70 \%$ respondentų cukriniu diabetu neserga, tačiau 5-10 metų laikotarpiu sergančiujų buvo daugiausia, t.y. 12\%. Todèl labai svarbu reguliariai stebèti gliukozès kiekị kraujyje.

Tyrimo metu buvo svarbu išanalizuoti pacientų žinias apie vykdomą širdies ir kraujagyslių ligų programą. Tyrimo duomenimis nustatyta, kad tik 34\% respondentų žino apie vykdomą širdies ir kraujagyslių ligų programą, 36\% žino apie programą tik iš dalies ir $30 \%$ nežino apie širdies ir kraujagyslių ligų vykdomas programas. Galima teigti, kad respondentai turi per mažai žinių apie vykdomą širdies ir kraujagyslių ligų programą. Todèl reikètų suteikti kuo daugiau informacijos šioje srityje, kadangi tik išsamiai susipažinus su šia programa ir žinant, kokia yra rizika susirgti širdies ir kraujagyslių ligomis, būtų galima jos išvengti. Analizuojant pacientų motyvaciją svarbu atsižvelgti ir i socialinès paramos aspektus: šeimos narių, draugų, kolegu palaikymą [4].

Tyrimo duomenimis nustatyta, kad didesnè dalis respondentų (51\%) informacijos apie ŠKL programas gaudavo iš šeimos gydytojo, kiek mažiau informacijos suteikè slaugytojos (30\%) (1 lentelè).

Tyrimo metu išryškejjo sritys, kuriose pacientai pakeitè gyvenimo ịpročius, dalyvaujant širdies ir kraujagyslių ligų programoje: „Mitybos ịpročių pokytis“, „Fizinio aktyvumo pokytis“, „Racionalus poilsis“. Nemaža dalis pacientu (11) džiaugèsi padidejjusiu fiziniu aktyvumu, tai iliustruoja vienas iš jų pasisakymų: „Pradejjau sportuoti, tapau žvalesnis“ (15 respondentas). Dalis pacientu (7) pakeitè mitybos ịpročius: „Pakeičiau mitybos ịpročius, atsisakau saldumynų, sumažinau druskos kiekị “. Pacientai, kurie dalyvavo programoje, pakeité požiūrị ị dienos réžimą (2), daugiau laiko skyrè poilsiui. Tai iliustruoja šie respondentų pasisakymai: „Pakeičiau dienos réžimą, daugiau laiko skiriu poilsiui“. Tyrimo metu atsiskleidè ir neigiamos programos pusés. Dalis respondentų (7) nepastebejjo teigiamų pokyčių, jiems pritrūko motyvacijos keisti gyvenimo įpročius: „, Nieko nepakeičiau“, „Neturiu noro ir galimybių kažką keisti“".

Galima teigti, kad daugumai pacientų reikalinga nuolatinè parama ir paskata keičiant gyvenimo ịpročius (2 lentelè). Tyrimo metu išryškejjo motyvai, dèl kurių respondentai 
keistų gyvenimo būdą: „Sveikatos pablogèjimo baimë“, „Komplikacijų baimè“, „Papildomos finansinès išlaidos“, „Teigiamos emocijos“.

Nemaža dalis pacientų (14) nurodo sveikatos pablogèjimo baimę kaip pagrindinị motyvą, dèl kurio keistų gyvenimo būdą: „Ligos paūmèjimo baimè, pakartotinis gydymas ligoninèje“ (4 respondentas), „Blogi tyrimai, bloga sveikata“( 13 respondentas). Komplikacijų baimè yra dažnas motyvas, dèl kurio pacientai keistų gyvenimo būdą. Tai iliustruoja šie pacientų pasisakymai: „Galvos svaigimas bei padidejęs kraujo spaudimas dèl netinkamo dienos rèžimo gali sukelti komplikacijas" ( 6 respondentas). Dalis respondentų (5) nurode papildomų finansinių išlaidų baimę: „Nežinau kas paskatintų keisti gyvenimo būdą. Pasigendu iš šeimos narių, gydytojų pagalbos. Pablogejus sveikatai reikès papildomai vaistų, kurie brangiai kainuoja“. Pacientai (4) įvardijo teigiamas emocijas, kurios skatina keisti gyvenimo ịpročius: „Tapau žvalesnis, geresnès nuotaikos“ (4 respondentas) (3 lentelè).

Tyrimo metu išryškejjo sveikatos būklès pokyčiai dalyvaujant širdies ir kraujagyslių ligų programoje:

„Svorio pokyčiai“, „Požiūrio ị sveikatą pokytis“, „Pagerejusi savijauta“ bei „Pokyčių nebuvimas“. Nemaža dalis pacientų (5) džiaugèsi kūno masès pokyčiais: „Nukrito svoris, sumažejo kraujo spaudimas“ (4 respondentas), „Sumažèjo pilvo apimtys" (11 respondentas). Dalis pacientų (2) nurodè požiūrio ị sveikatą pokytị. Tai iliustruoja šie respondentų pasisakymai: „Pakeičiau požiūrị ị savo sveikatą, sveikiau maitinuosi, atsisakau riebaus maisto, daugiau judu. Pradžioje buvo sunku, tačiau šiuo metu tai tampa ịpročiu“. Likusi dalis respondentų pokyčių nepastebejjo (11) dèl žinių stokos, neturejjimo motyvacijos: „Suteikè informaciją, kad reikalinga keisti gyvenimo ịpročius, tačiau trūksta žinių kaip tai igyvendinti“ (2 respondentas), „Nepasikeitè, neturiu jègų, motyvacijos keisti ịpročių“(4 respondentas).

\section{Išvados}

1. Širdies ir kraujagyslių ligos jau daugelị metų yra pagrindinè mirties priežastis Lietuvoje. Kiekvienais metais širdies ir kraujagyslių ligomis suserga daugiau nei 4 milijonai žmonių, Europos Sajungoje miršta daugiau nei 1,9 mln. gyventojų. Širdies ir kraujagyslių ligų išsivystymui įtakos turi rizikos veiksniai: padidejęes cholesterolio kiekis kraujyje, cukrinis diabetas, padidejęs kraujo spaudimas, nutukimas, rūkymas, netinkama mityba, mažas fizinis aktyvumas.

2. Pacientams suteikiama per mažai informacijos apie vykdomas širdies ir kraujagyslių ligu programas. Tyrime dalyvavusių respondentų požiūriu vykdoma programa buvo naudinga tik iš dalies.

3. Ketvirtadalis respondentų nurodé, kad pasigenda
3 lentelè. Sveikatos būklès pokyčiai dalyvaujant širdies ir kraujagyslių ligų programoje $(\mathrm{N}=27)$

\begin{tabular}{|c|c|c|}
\hline $\begin{array}{l}\text { Katego- } \\
\text { rija }\end{array}$ & $\begin{array}{c}\text { Kar- } \\
\text { totinių } \\
\text { skaičius }\end{array}$ & Autentiški pasisakymų fragmentai \\
\hline $\begin{array}{l}\text { Kūno } \\
\text { masės } \\
\text { pokyčiai }\end{array}$ & 5 & $\begin{array}{l}<. \text { Nukrito svoris, sumažèjo kraujo } \\
\text { spaudimas..> (4 respondentas) } \\
<\text {..Sumažèjo pilvo apimtys..> }(11 \\
\text { respondentas) } \\
<. . \text { Stabilizavosi svoris..> ( } 7 \text { respon- } \\
\text { dentas) }\end{array}$ \\
\hline $\begin{array}{l}\text { Požiūrio } \\
\text { i sveikatą } \\
\text { pokytis }\end{array}$ & 2 & $\begin{array}{l}\text { <..Pakeičiau požiūrị i c savo sveikatą, } \\
\text { sveikiau maitinuosi, atsisakau rie- } \\
\text { baus maisto, daugiau judu. Pradžioje } \\
\text { buvo sunku, tačiau šiuo metu tai tam- } \\
\text { pa įpročiu..> (15 respondentas) }\end{array}$ \\
\hline $\begin{array}{l}\text { Pagerè- } \\
\text { jusi savi- } \\
\text { jauta }\end{array}$ & 9 & $\begin{array}{l}<. \text {.Pagerèjo savijauta, sumažèjo kūno } \\
\text { masè..> ( } 4 \text { respondentas }) \\
<. . \text { Teigiamai, netekau kelių kilogra- } \\
\text { mų..> }(15 \text { respondentas }) \\
<. . \text { Vertinu teigiamai, stebiu sveikatos } \\
\text { pagerèjimą.. }>\text { ( } 8 \text { respondentas }) \\
<. . \text { Pagerejjusi savijauta.. }>\text { (18 respon- } \\
\text { dentas) }\end{array}$ \\
\hline $\begin{array}{l}\text { Niekas } \\
\text { nepakito }\end{array}$ & 11 & $\begin{array}{l}<. \text { Suteikė informaciją, kad reikalin- } \\
\text { ga keisti gyvenimo ịpročius, tačiau } \\
\text { trūksta žinių, kaip tai igyvendinti.. } \\
(2 \text { respondentas) } \\
<\text {.Nepasikeite, neturiu jègų, motyva- } \\
\text { cijos keisti ịpročių. }>\text { ( } 4 \text { respondentas) } \\
<\text {.Nebuvo nieko gero. }>\text { (16 respon- } \\
\text { dentas) }\end{array}$ \\
\hline
\end{tabular}

slaugytojos informacijos apie vykdomas programas. Daugiau nei pusè apklaustujų nurodé, kad slaugytojos nepakankamai aiškiai ir suprantamai suteikia informaciją apie programos reikalingumą. Pacientai pasigenda šeimos narių palaikymo, skatinimo dalyvauti prevencinèje programoje.

4. Tyrimo duomenimis, didesnè dalis respondentų daugiau norètų sužinoti apie ligos rizikos veiksnius - padidèjusị cholesterolio ir gliukozès kiekị kraujyje, neracionalią mitybą bei stresą.

5. Respondentų požiūriu priimtiniausias būdas informacijai suteikti yra individualus mokymas, mokymas grupése, kiek mažiau - nuotolinis mokymas bei skaitymas ir domejjimasis medicinine literatūra. Daugumai respondentų reikalinga nuolatine motyvacija ir paskata iš išorès.

Galima teigti, kad pacientai supranta širdies ir kraujagyslių ligų programos svarbą teoriniu lygmeniu, tačiau nepakankamai iggvendina praktiškai. 


\section{Literatūra}

1. Clark AM, Flynn R, Hsu ZY, Haykowsky M. Heart failure with preserved ejection fraction: health services implications of a stealth syndrome, Europian Journal of Cardiovascular Nurs. 2013; 12 (4) [interaktyvus], [žiūrèta 2015 m. birželio 6 d].

2. WHO/Europe, European HFA Database, 2013 [interaktyvus], [žiūrèta 2015 m. rugsėjo $11 \mathrm{~d}$ ] Prieiga per internetą: http://data. euro.who.int/hfadb/tables/tableA.php?w=1440\&h=900.

3. Higienos instituto Sveikatos informacijos centras, 2014 [interaktyvus], [žiūrèta $2015 \mathrm{~m}$. birželio 16 d] Prieiga per internetą: http://sic.hi.lt.

4. Årestedt K. et al. Social support and its association with healthrelated quality of life among older patients with chronic heart failure, Europian Journal of Cardiovascular Nurs. 2013: 69-77.

5. Leterme Y, Coggi PT. Health at a Glance: Europe 2012.

6. LR SAM ministro $2005 \mathrm{~m}$. lapkričio $25 \mathrm{~d}$. ịsakymas Nr. V-913 „Dèl asmenų, priskirtinų širdies ir kraujagyslių ligų didelès rizikos grupei, atrankos ir prevencijos priemonių finansavimo programos patvirtinimo" [interaktyvus], [žiūrèta $2015 \mathrm{~m}$. rugsejjo $5 \mathrm{~d}$ ].

7. Nichols M, Townsend N, Scarborough P, Rayner M ( 2012). European Cardiovascular Disease Statistics, European Heart Network, Brussels, European Society of Cardiology, Sohia Antipolis 2012. Prieiga per internetą: http://www.escardio.org/ about/documents/eu-cardiovascular-disease-statistics-2012.pdf

8. Gallagher R. Self Management, Symptom Monitoring and Associated Factors in People with Heart Failure Living in the Community, Eur J Cardiovasc Nurs 2012, 12 (11).
9. Verseckaitè R. Kardiologijos naujovès: Lietuvos bendrosios praktikos gydytojas; 2009 (1); 66 [interaktyvus], [žiūrèta 2015 m. rugsèjo $5 \mathrm{~d}]$.

\section{PATIENTS APPROACH TO CARDIOVASCULAR DIS- EASES AND THEIR PREVENTION PROGRAMS}

\section{Rasteniené, L. Lastauskiené}

Key words: cardiovascular disease, cardiovascular disease prevention.

The study involved 50 respondents. There were 32 women (64\%) and 18 males (36\%). Respondents were selected according to age, belonging to a high risk group of women aged from 50 to 65 , men aged from 40 to 55 years of age.

The results showed that patients have little knowledge about the ongoing program for cardiovascular diseases. Most of the information about the program, health and the ways to strengthen it has been received from family doctors and nurses; however, patients found very little or did not find any information in newspapers and magazines. Also, it was found that patients understand the importance of cardiovascular diseases at the theoretical level, but that does not translate into practice. Patients welcomed the healthy way of life, but many failed to follow the advice. Many ran out of intrinsic motivation and have expected incentives, reminders and personal attention from nurses.

Correspondens to: vilma.rastenienė@go.kauko.lt

Gauta 2015-10-14 